\title{
Efektivitas Pendapatan Usaha Pada Perusahaan Daerah Air Minum (PDAM) Tirta Musi Kota Palembang
}

\author{
Reni Apriani \\ Fakultas Ilmu Sosial dan Ilmu Politik Universitas Islam Negeri Raden Fatah Palembang \\ reniapriani_uin@radenfatah.ac.id
}

\begin{abstract}
This research is titled Effectiveness of Operating Revenue On Regional Water Company (PDAM) Tirta Musi Palembang. This study was aimed to find out how the operating revenue of PDAM Tirta Musi Palembang, and also to find out factors that inhibiting the operating revenue of PDAM Tirta Musi Palembang. The method used in this research was a qualitative method. The results showed that revenues have not been effective because the target was not achieved and non-water sales revenue was decreased. The input owned by PDAM Tirta Musi Palembang was good. However, PDAM Tirta Musi Palembang still has not done well in utilizing the water. The feedback conducted by PDAM Tirta Musi Palembang was quite good, although not as a whole. There were also 2 inhibiting factor in the operating revenues of PDAM Tirta Musi Palembang, namely: the internal factor s which were the limited human resources and a low level of supervision, and the external factors which were the lack of customer awareness in paying water bills and frauds that occurs in society.
\end{abstract}

Keywords: effectiveness, operating revenue

\begin{abstract}
Abstrak
Penelitian ini berjudul Efektivitas Pendapatan Usaha pada Perusahaan Daerah Air Minum (PDAM) Tirta Musi Palembang. Penelitian ini bertujuan untuk mengetahui bagaimana pendapatan usaha PDAM Tirta Musi Kota Palembang dan juga untuk mengetahui faktor-faktor yang menjadi penghambat dalam pendapatan usaha pada PDAM Tirta Musi Kota Palembang. Metode yang digunakan dalam penelitian ini adalah metode kualitatif. Hasil penelitian menunjukkan bahwa pendapatan usaha belum efektif. Masukan yang dimiliki PDAM Tirta Musi Kota Palembang sudah baik. Dalam memprosese air, PDAM Tirta Musi Kota Palembang masih belum melakukan proses dengan baik dalam memanfaatkan air. Hasil yang didapat oleh PDAM Tirta Musi Kota Palembang pada pendapatan usaha belum efektif, disebabkan oleh tidak tercapainya target dan pendapatan penjualan non air mengalami penurunan. Serta dalam penanganan feedback yang dilakukan oleh PDAM Tirta Musi Kota Palembang sudah teratasi cukup baik walaupun belum secara keseluruhan. Terdapat 2 faktor penghambat dalam pendapatan usaha PDAM Tirta Musi Kota Palembang, yaitu
\end{abstract}


faktor internal adanya keterbatan sumber dayamanusia dan rendahnya tingkat pengawasan. Faktor eksternal masih kurangnya kesadaran pelanggan dalam membayar air dan adanya kecurangan yang terjadi didalam masyarakat.

Kata kunci : Efektivitas, Pendapatan Usaha

\section{PENDAHULUAN}

Penyelenggaraan pemerintahan Negara Kesatuan Republik Indonesia dibagi atas pemerintahan pusat dan pemerintahan daerah. Pemerintahan Daerah terdiri atas pemerintahan daerah provinsi dan pemerintahan daerah kabupaten dan kota sehingga setiap daerah mempunyai hak dan kewajiban dalam mengatur dan mengurusi sendiri urusan pemerintahannya. Dalam menunjang penyelenggaraan pemerintahan dan pembangunan di daerah secara merata, maka dilakukan pendayagunaan aparatur pemerintah dengan pelaksanaan dan adanya pengawasan yang efektif sehingga pembangunan nasional dapat berjalan dengan baik. Pendapatan daerah merupakan pendapatan pemerintah daerah yang bersumber dari hasil pajak daerah, hasil retribusi daerah dan hasil pengelolaan kekayaan daerah yang dipisahkan serta lain-lain pendapatan asli daerah yang sah sehingga pemerintah pusat memberikan keleluasaan kepada daerah dalam menggali dana didaerahnya masing-masing guna pelaksanaan otonomi daerah sebagai perwujudan asas desentralisasi.

Upaya peningkatan Pendapatan Asli Daerah dapat dilakukan dengan cara meningkatkan sumber daya yang sudah ada, dalam hal ini adalah hasil perusahaan daerah. Hasil perusahaan daerah dapat diartikan sebagai laba dari perusahaan daerah yang berupa persentase tertentu dari laba bersih perusahaan daerah menurut cara-cara yang telah ditentukan di dalam anggaran dasarnya. Dalam rangka memberikan pelayanan publik yang baik kepada masyarakat Kota Palembang, khususnya dibidang pelayanan air bersih, maka pemerintah mendirikan Perusahaan Daerah Air Minum yang bernama Perusahaan Daerah Air Minum (PDAM) Tirta Musi. Perusahaan ini disamping berperan untuk menyediakan air bersih bagi masyarakat Kota Palembang juga diharapkan mendatangkan pendapatan bagi pemerintah Kota Palembang, namun salah satu pendapatan PDAM Tirta Musi Kota Palembang, yaitu: pendapatan usaha yang diharapkan tidak memenuhi persyaratan, hal ini bisa dilihat dari:

\section{Target yang ditetapkan tidak tercapai}

Perusahaan Daerah Air Minum (PDAM) Tirta Musi berdasarkan laporan keuangannya mempunyai 2 jenis pendapatan, yaitu: Pendapatan usaha dapat diartikan sebagai pendapatan yang berhubungan langsung dengan kegiatan usaha. Contoh: hasil dari penjualan air. Dan Pendapatan diluar usaha adalah pendapatan yang tidak berhubungan langsung dengan kegiatan usaha.Contoh: bunga deposito. Kedua jenis pendapatan Perusahaan Daerah Air Minum (PDAM) Tirta Musi ini sangat berkontribusi dalam kelancaran suatu aktivitas perusahaan. Hasil dari pendapatan usaha maupun 
pendapatan diluar usaha bisa saja menerima laba atau rugi pada perusahaan tergantung dari aktivitas yang dilakukan oleh perusahaan tersebut.

\section{Pendapatan Penjualan Non Air mengalami penurunan}

Pendapatan penjualan non air ini berasal dari pendapatan usaha, dimana penerimaan air dan non air adalah bagian dari aktivitas atau terkait erat dengan penyerahan air bersih yang dialirkan melalui pipa karena merupakan pendapatan yang berasal dari persyaratan mutlak yang harus dipenuhi untuk menghasilkan air bersih agar dapat dialirkan kerumah pelanggan atau masyarakat sehingga pendapatan penjualan non air termasuk dalam pengertian air bersih yang disalurkan melalui pipa oleh Perusahaan Air Minum, dalam hal ini PDAM Tirta Musi Kota Palembang. Pendapatan ini juga berperan dalam memberikan kontribusinya terhadap pendapatan usaha pada PDAM Tirta Musi Kota Palembang.

Mengingat pentingnya suatu pendapatan pada PDAM Tirta Musi Kota Palembang untuk meningkatkan pendapatan perusahaan dalam hal ini pada pendapatan usaha PDAM Tirta Musi Kota Palembang, untuk itulah perlu dikaji lebih mendalam mengenai pendapatan usaha PDAM Tirta Musi Kota Palembang. Pendapatan usaha di PDAM Tirta Musi ini terdiri dari: pendapatan penjualan air dan pendapatan penjualan non air, dari kedua jenis pendapatan usaha tersebut sangat diharapkan mendatangkan pendapatan yang efektif bagi PDAM Tirta Musi Kota Palembang.

Berdasarkan yang telah diuraikan dilatar belakang, maka masalah yang timbul adalah:

a) Bagaimana pendapatan usaha PDAM Tirta Musi Kota Palembang?

b) Faktor-faktor apa saja yang menjadi penghambat dalam pendapatan usaha PDAM Tirta Musi Kota Palembang?

Tujuan penelitian dapat dirumuskan dengan permasalahan tersebut diatas sebagai berikut:

a) Untuk mengetahui bagaimana pendapatan usaha PDAM Tirta Musi Kota Palembang

b) Untuk mengetahui faktor-faktor yang menjadi penghambat dalam pendapatan usaha PDAM Tirta Musi Kota Palembang

Penelitian ini akan merujuk kepada beberapa teori, khususnya yang berkenaan dengan efektivitas pendapatan perusahaan daerah. Selanjutnya, beragam teori tersebut akan didefinisikan seperti berikut ini:

a) Efektivitas Pendapatan Perusahaan Daerah

Efektivitas adalah keberhasilan suatu organisasi yang dalam hal ini adalah organisasi pemerintah didalam mengemban tugas pokok dan fungsi pemerintahan. Efektivitas menunjukan keberhasilan dari segi tercapai tidaknya sasaran yang telah ditetapkan. Efektif mengarah pada pengertian ketetapan atau kesesuaian antara usaha yang dilakukan dengan tujuan yang telah ditentukan. Menurut Peraturan Menteri Dalam Negeri Nomor 13 Tahun 2006 tentang Pedoman Pengelolaan Keuangan Daerah mengemukakan bahwa efektif merupakan pencapaian hasil program dengan target yang telah ditetapkan, yaitu dengan cara membandingkan keluaran dengan hasil. 
b) Pendapatan Usaha PDAM Tirta Musi Kota Palembang

Pendapatan adalah suatu hasil dari kerja yang dilakukan, pada dasarnya adanya jumlah uang yang diterima oleh perusahaan dari aktivitasnya, kebanyakan dari penjualan produk dan/atau jasa kepada pelanggan, dalam hal ini pada Perusahaan Daerah Air Minum (PDAM) Tirta Musi Kota Palembang. Perusahaan Daerah Air Minum (PDAM) Tirta Musi Kota Palembang didirikan dengan tujuan memberikan pelayanan kepada masyarakat untuk menyediakan air bersih serta memberikan kontribusi dalam bentuk Pendapatan Asli Daerah. Maka dari itulah, suatu pendapatan PDAM Tirta Musi Palembang sangat potensial dalam menunjang keberhasilan perusahaan dan juga berkontribusi pada pemerintah daerah Kota Palembang.

Pendapatan Usaha dapat diartikan sebagai pendapatan yang berhubungan langsung dengan kegiatan usaha. Berdasarkan laporan keuangan perusahaan, Pendapatan Usaha Pada Perusahaan Daerah Air Minum (PDAM) Tirta Musi Kota Palembang terdapat 2 jenis pendapatan usaha, yaitu:

a) Pendapatan penjualan air

Pendapatan penjualan air merupakan hasil dari aktivitas yang dilakukan oleh perusahaan atas penjualan air bersih ke pelanggan. Pendapatan penjualan air terdiri dari :

1. Rekening

2. Mobil tangki

b) Pendapatan penjualan non air

Pendapatan penjualan non air berasal dari pendapatan usaha, penerimaan penjualan non air adalah bagian dari aktivitas atau terkait erat dengan penyerahan air bersih yang dialirkan melalui pipa karena merupakan pendapatan yang berasal dari persyaratan mutlak yang harus dipenuhi untuk menghasilkan air bersih agar dapat dialirkan kerumah pelanggan atau masyarakat sehingga pendapatan penjualan non air termasuk dalam pengertian air bersih yang disalurkan melalui pipa oleh Perusahaan Air Minum, dalam hal ini PDAM Tirta Musi Kota Palembang. Pendapatan penjualan non air di PDAM Tirta Musi terdiri dari : 1. Balik nama, 2. Sambungan instalansi, 3. Sambungan kembali, 4. Biaya administrasi, 5. Ganti meter, 6. Penggantian pipa persil, 7.Non air lainnya, 8. Pemeriksaan laboratorium

Kedua jenis pendapatan usaha pada Perusahaan Daerah Air Minum (PDAM) Tirta Musi ini sangat berkontribusi dalam kelancaran suatu aktivitas perusahaan. Hasil dari pendapatan penjualan air maupun pendapatan penjualan non air bisa saja menerima laba atau rugi pada perusahaan tergantung dari aktivitas yang dilakukan oleh perusahaan tersebut.

Jadi, Pendapatan Usaha Perusahaan Daerah Air Minum (PDAM) Tirta Musi Kota Palembang adalah suatu hasil yang diterima perusahaan, berupa uang atas aktivitas yang dilakukan dari penyediaan air bersih kepada masyarakat dengan kualitas dan kuantitas yang sesuai dengan standar yang ditetapkan, baik dari penjualan air maupun penjualan non air.

Penulis dalam menganalisis masalah yang ada menggunakan Efektivitas yang digunakan menurut pendapat Gibson (1990), adanya kriteria penilaian keefektifan dengan perspektif system mulai dari input, proses, output dan feedback (timbal balik). Perspektif Sistem menyatakan bahwa 
adanya keterpaduan dari berbagai unsur dalam suatu sistem yang saling berhubungan dan saling tergantung antara satu dengan yang lain. Perspektif system merupakan model yang paling tepat digunakan dalam menilai efektivitas pendapatan PDAM Tirta Musi Kota Palembang sehingga usaha membahas efektivitas organisasi secara menyeluruh lebih tepat. Hal ini didukung dengan kenyataan bahwa sulitnya mempersamakan efektivitas organisasi dengan tingkat keberhasilan dalam pencapaian tujuan, karena selalu ada penyesuaian dalam target yang akan dicapai, juga dalam proses pencapaian seringkali dipengaruhi faktor dari keadaan sekeliling organisasi.

Dilihat dari komponen yang terdapat dalam model perspektif system, adanya keterpaduan unsur dalam suatu sistem yang saling berhubungan dan saling tergantung antara satu dengan yang lain berupa input Perusahaan Daerah Air Minum (PDAM) Tirta Musi ini menyediakan bahan atau masukan seperti: sumber air baku, jumlah zat kimia dan sebagainya yang digunakan untuk proses yang dilakukan melalui beberapa proses pengolahan air sehingga adanya output yang menghasilkan air bersih dan air bersihpun bisa didistribusikan ke pelanggan dan mendapatkan pendapatan perusahaan serta umpan balik dari lingkungan terhadap masukan, pengolahan dan keluaran. Jadi, efektivitas adalah ukuran keberhasilan dalam mencapai tujuan tertentu yang didasarkan pada input, proses, output dan feedback (timbal balik).

\section{METODE PENELITIAN}

Penelitian ini mengenai bagaimana efektivitas pendapatan perusahaan daerah air minum (PDAM) Tirta Musi Kota Palembang. Oleh karena itu pengumpulan data dilakukan pada PDAM Tirta Musi tersebut, karena pegawai yang ada pada PDAM Tirta Musi yang paling mengetahui tentang pendapatan perusahaan, dalam hal ini PDAM Tirta Musi Kota Palembang. Pengumpulan data dilakukan dengan cara melakukan wawancara mendalam. Jadi, penelitian ini menggunakan desain penelitian dengan metode kualitatif, khususnya yang berkenaan dengan sumber data, teknik pengumpulan data, teknik analisis data, maupun sifat data yang utama.

Sumber data utama dalam penelitian kualitatif adalah kata-kata dan tindakan selebihnya adalah data tambahan seperti dokumen dan lain-lain. Adapun sumber data yang digunakan dalam penelitian ini terdiri dari :

a) Data primer yaitu data yang diperoleh secara langsung dari objek penelitian dengan cara wawancara secara langsung dengan pihak-pihak yang relavan dalam memberikan informasi yang terkait dengan masalah yang diteliti. Pihak yang relevan pada penelitian ini adalah Bagian Keuangan pada PDAM Tirta Musi Kota Palembang.

b) Data sekunder yaitu data primer yang telah diolah dan disajikan baik oleh pihak pengumpul data primer atau oleh pihak lainnya. Data sekunder yang digunakan dalam penelitian ini berupa dokumen, buku-buku, literatur, Peraturan Daerah, arsip, dan Laporan Keuangan PDAM Tirta Musi Kota Palembang. 
Untuk mengetahui bagaimana efektivitas pendapatan usaha pada PDAM Tirta Musi Kota Palembang, maka peneliti melakukan wawancara dan membuat dokumentasi terhadap key informants. Key Informants dalam penelitian ini adalah : 1. Kepala Bagian Pembukuan dan Komputer, 2.Kepala Bagian Perencanaan, 3. Kepala Seksi Pembukuan, 4.Kepala Seksi SDM, 5. Tim Auditor, 6. Pelanggan PDAM Tirta Musi Kota Palembang sebanyak 5 orang

\section{HASIL DAN PEMBAHASAN}

Kajian ini menggunakan pendekatan system sebagai acuan dalam mengetahui efektivitas pendapatan usaha pada PDAM Tirta Musi Kota Palembang. Setelah mengkaji bagaimana efektivitasnya, kemudian akan dilanjutkan dengan pengkajian factor-faktor yang menjadi penghambat dalam pendapatan usaha. Pembahasan ini ,erujuk pada teori yang dijadikan referensi, yaitu teori efektivitas yang diungkapkan oleh Gibsin dkk, yang mana teori memiliki 4 dimensi kriteria keefektifan, yaitu: input, proses, output dan feedback yang menjadi tolak ukur berhasil atau tidaknya efektivitas pendapatan usaha pada PDAM Tirta Musi Kota Palembang.

A. Dimensi Input

1. Air Baku PDAM Tirta Musi Kota Palembang bersumber dari 2 sungai yang ada di Palembang, yaitu: sungai musi dan sungai ogan. Kedua sungai tersebut adalah sungai yang besar dan panjang. Sungai tersebut menyediakan jumlah air yang sangat banyak dan dengan kualitas yang memadai.

2. Sarana dan Prasarana PDAM Tirta Musi Kota Palembang sudah cukup memadai dengan fasilitas-fasilitas yang tersedia. Ada 33 jenis sarana dan prasarana dengan jumlah perunitnya masing-masing. Sarana dan Prasarana yang sudah ada dapat mempermudah kerja para pegawai.

3. Sumber daya manusia PDAM Tirta Musi memiliki mekanisme kerja yang ada sesuai dengan keputusan Direksi nomor:57/KPTS/UP/PDAM /2012 tanggal 14 September 2012, yang memiliki beberapa jenis pegawai terdiri dari: PNS, pgawai perusahaan, calon pegawai dan tenaga kontrak. Jumlah pegawai PDAM Tirta Musi Kota Palembang sebanyak 577 orang.

4. Jumlah Zat Kimia. Zat kimia merupakan salah satu masukan sebagai penyedia air bersih pada PDAM Tirta Musi Kota Palembang. Zat Kimia yang digunakan PDAM Tirta Musi, terdiri: Aluminium Sulfat, Kapur, Gas chlor, Kaporit, dan Soda asih.

5. Modal. Dari Laporan Keuangan PDAM Tirta Musi Kota Palembang. Modal PDAM Tirta Musi terdiri dari kekayaan daerah yang dipisahkan dengan keputusuan DPRD.

Kekayaan tersebut yaitu:

a) Penyisihan sebagian keuangan daerah yang dicantumkan dalam APBD

b) Bantuan atau subsidi Pemerintah Daerah Provinsi Sumatera Selatan

c) Bantuan atau subsidi Pemerintaha Pusat

d) Pinjaman serta Bantuan lainnya 


\section{B. Dimensi Proses}

Dalam pengolahan membutuhkan waktu dan selanjutnya terdapat beberapa indicator proses pengolahan air, yaitu:

1. Proses Koagulasi (pengadukan cepat)merupakan proses pencampuran bahan koagulan dengan koloid yang terdapat pada air baku, yang bertujuan agar kotoran-kotoran pada air baku dapat diperbesar partikelnya sehingga akibat menggumpalnya partikel tersebut kotoran-kotoran tersebut dapat tenggelam dengan sendirinya.

2. Proses Flokulasi (pengadukan lambat) dilakukan didalam unit flokulator. Pada bak ini aliran diatur sedemikian rupa agar flok yang terbentuk akibat reaksi kimia zat koagulan dengan partikel koloid dapat menjadi besar sehingga mudah diendapkan. Kemudiaan dialirkan secara gravitasi menuju unit pengendapan.

3. Proses Sedimentasi (pengendapan) adalah salah satu unit proses yang umum dalam pengolahan air, baik sedimentasi berfungsi untuk memisahkan (mengendapkan) flok-flok yang terbentuk dengan penambahan zat kimia.

4. Proses Filtrasi (penyaringan) merupakan proses penjernihan yang berfungsi untuk menyaring partikel-partikel padat yang tidak mengendap pada bak sedimentasi.

5. Proses Disinfeksi (pembubuhan disinfektan) Air yang keluar dari filter, telah jernih dan secara fisik telah memenuhi standar kualitas air bersih, namun masih perlu dilakukan proses disinfeksi, yaitu proses pembubuhan gas chlor atau kapur dengan tujuan agar bakteri atau kuman yang terkandung dalam air dapat dihilangkan

6. Pusat Distribusi (Booster), Pendistribusian air kepelanggan yang lokasinya jauh dari instalansi pengolahan air (IPA) dilakukan melalui sistem pusat distribusi (booster) dengan menggunakan pompa.

\section{Dimensi Output}

Air bersih yang dihasilkan oleh PDAM Tirta Musi Kota Palembang ini telah memenuhi standar kualitas yang ditetapkan, yaitu: berdasarkan keputusan Menteri Kesehatan RI No.492 Tahun 2010 tentang kualitas air minum.

Perusahaan Daerah Air Minum (PDAM) menggunakan Istilah tarif untuk harga jual air. Tarif air minum merupakan biaya jasa pelayanan air minum yang wajib dibayarkan oleh pelanggan untuk setiap pemakaian air minum yang diberikan oleh perusahaan atau penyelenggara.

Pendapatan usaha perusahaan

Pendapatan adalah hasil kerja yang dilakukan, pada dasarnya adanya jumlah uang yang diterima oleh perusahaan dari aktivitasnya, kebanyakan dari penjualan produk atau jasa kepada pelanggan, dalam hal ini Perusahaan Daerah Air Minum (PDAM) Tirta Musi Kota Palembang menyediakan air bersih dan menerima pendapatan perusahaan. 


\section{Dimensi Feedback}

Feedback merupakan penerima umpan balik dari lingkungan terhadap kegiatan masukan, pengolahan dan keluaran. Pengaduan diartikan sebagai permintaan oleh pelanggan kepada PDAM untuk mengatasi kendala atau tindakan yang merugikan. PDAM Tirta Musi Kota Palembang banyak mengalami kendala sebagai penyedia air bersih bagi masyarakat Kota Palembang. Sosialisasi adalah proses yang berlangsung sepanjang hidup manusia. Dalam sosialisi terjadi saling pengaruh antara individu beserta segala potensi kemanusiaannya, dengan masyarakat beserta kebudayaannya. PDAM Tirta Musi Kota Palembang tahun 2013 sebagai penerima umpan balik dari lingkungan terhadap kegiatan masukan, pengolahan dan keluaran sudah cukup baik untuk masyarakat Kota Palembang.

Pembahasan di atas menunjukkan bahwa pendapatan usaha pada Perusahaan Daerah Air Minum (PDAM) Tirta Musi Kota Palembang Tahun 2013 adalah belum efektif. Secara kualitatif, hasil pembahasan untuk variabel efektivitas pendapatan usaha pada Perusahaan Daerah Air Minum (PDAM) Tirta Musi Kota Palembang yang terdiri dari dimensi input, proses, output dan feedback.

Merujuk pada teori yang dijadikan referensi, yaitu teori yang terdapat pada tulisan Gibson dkk, yang menyatakan bila tingkat input sudah baik, proses belum dapat dilakukan dengan baik, belum terwujudnya output dan feedback yang diinginkan. Maka, pendapatan usaha pada Perusahaan Daerah Air Minum (PDAM) Tirta Musi Kota Palembang dapat dikatakan belum efektif. Jadi, tidak selaras antara teori dengan praktiknya dilapangan.

Untuk mengetahui faktor-faktor apa saja yang menjadi penghambat dalam pendapatan usaha pada Perusahaan Daerah Air Minum (PDAM) Tirta Musi Kota Palembang Tahun 2013, faktor-faktor tersebut adalah:

\section{A. Faktor internal}

Keterbatasan pengetahuan SDM merupakan salah satu kendala bagi perusahaan, terutama dalam aspek-aspek manajemen, administrasi, akuntansi, data processing dan teknik produksi. Sedangkan semua keahlian ini sangat dibutuhkan untuk mempertahankan keahlian atau memperbaiki kualitas produksi dan meningkatkan efektivitas pendapatan perusahaan.

Tingkat Pengawasan

Salah satu faktor yang menjadi penghambat dalam pendapatan usaha pada PDAM Tirta Musi Kota Palembang adalah rendahnya tingkat pengawasan pada aktivitas yang dilakukan perusahaan. Perusahaan Daerah Air Minum (PDAM) Tirta Musi Kota Palembang terdapat perbedaan jumlah air baku dengan hasil air produksi yang didapat perusahaan. Hal tersebut menimbulkan asumsi bahwa PDAM Tirta Musi Kota Palembang kurang dalam mengawasi berjalannya suatu aktivitas penyediaan air bersih, khususnya dalam tahap proses air.

B. Faktor eksternal.

Kesadaran pelanggan

Perusahaan Daerah Air Minum (PDAM) Tirta Musi Kota Palembang bertujuan menyediakan air bersih bagi pelanggan perusahaan. namun pelanggan PDAM Tirta Musi masih kurang kesadaran dalam membayar air secara tepat waktu. Hal ini sangat merugikan perusahaan 
dan juga mengakibatkan terhambatnya pendapatan usaha yang dihasilkan oleh PDAM Tirta Musi Kota Palembang.

Kecurangan

Perusahaan Daerah Air Minum (PDAM) Tirta Musi Kota Palembang sudah menyediakan air bersih kepada pelanggan, namun ditemukan bahwa adanya masyarakat yang melakukan pengerusakan pada alat peneran air (water meter) dan melakukan pencurian air sehingga merugikan PDAM Tirta Musi Kota Palembang.

\section{KESIMPULAN}

Berdasarkan analisis mengenai efektivitas pendapatan usaha pada Perusahaan Daerah Air Minum (PDAM) Tirta Musi Kota Palembang, disimpulkan bahwa pendapatan usaha pada PDAM Tirta Musi Kota Palembang belum efektif. Berikut adalah hasil analisis dari empat dimensi menurut Gibson dkk (1990:31) : 1. Masukan pada Perusahaan Daerah Air Minum (PDAM) Tirta Musi Kota Palembang dalam menjalankan aktivitas perusahaan yang dimiliki sudah baik, 2. Perusahaan Daerah Air Minum (PDAM) Tirta Musi Kota Palembang dalam memproses air, dapat dikatakan belum melakukan proses dengan baik. Sebab, masih adanya kehilangan air dalam proses tersebut. Sejauh ini, PDAM Tirta Musi Kota Palembang masih kurang baik dalam memanfaatkan air sebagai proses penyedia air bersih bagi masyarakat Kota Palembang, 3. Pendapatan usaha PDAM Tirta Musi adalah belum efektif. Hal ini disebabkan oleh tidak tercapainya target yang ditetapkan dan salah satu pendapatan usaha yaitu pendpatan penjualan non air mengalami penurunan. Maka dari itu, pendapatan usaha masih tergolong kurang baik dalam memperoleh pendapatan, 4. Perusahaan Daerah Air Minum (PDAM) Tirta Musi Kota Palembang sebagai penerima umpan balik dari lingkungan terhadap kegiatan masukan, pengolahan dan keluaran sudah cukup baik, tetapi ada beberapa yang masih belum teratasi, yaitu: keluhan pelanggan. Keluhan yang timbul cukup banyak, namum PDAM Tirta Musi ini telah melakukan perbaikan dari berbagai keluhan tersebut walaupun belum secara keseluruhan.

Faktor-faktor yang menjadi penghambat dalam pendapatan usaha Perusahaan Daerah Air Minum (PDAM) Tirta Musi Kota Palembang, faktor-faktor tersebut seperti keterbatasan pengetahuan SDM pada Perusahaan Daerah Air Minum (PDAM) Tirta Musi Kota Palembang menjadi penghambat, dilhat dari sumber daya manusia masih rendah dalam tingkat pendidikannya. Selain itu, tingkat pengawasan pada PDAM Tirta Musi Kota Palembang masih tergolong rendah. Hal ini diketahui pada proses dari aktivitas tersebut bahwa masih adanya kehilangan air sehingga menyebabkan perbedaan dari air baku yang diambil sebelumnya dengan hasil air produksi serta hasil air distribusi yang didapat perusahaan.

Berdasarkan temuan dan penjelasan tersebut maka dapat disimpulkan bahwa faktor- faktor yang menjadi penghambat dalam efektivitas pendapatan Perusahaan Daerah Air Minum (PDAM) Tirta Musi Kota Palembang adalah faktor eksternal, yaitu: keterbatasan pengetahuan SDM dan tingkat pengawasan. Dan faktor internal yaitu: kesadaran pelanggan. 
Penulis menyarankan kepada pihak PDAM Tirta Musi Kota Palembang untuk lebih memperhatikan SDM yang dimiliki untuk meningkatkan kinerja dan mendapatkan hasil yang diharapkan sesuai visi dan misi perusahaan. Selain itu, kepada pegawai PDAM Tirta Musi Kota Palembang untuk selalu mengawasi dan memiliki komunikasi yang baik antar pegawai dalam proses penyediaan air bersih agar tidak adanya kehilangan air. 


\section{DAFTAR PUSTAKA}

Basuki, S.H. (2010). Pengelolaan Keuangan Daerah. Yogyakarta

Djaenuri, Aries. (2012). Hubungan Keuangan Pusat-Daerah, Penerbit Ghalia Indonesia, Jakarta.

Gibson, Ivancevich, Donnely. (1990). Organisasi perilaku, struktur, proses. Terjemahan Oleh Agus Dharma. Jakarta: Penerbit Erlangga

Halim Abdul. (2007). Akuntansi dan pengendalian Pengelolaan Keuangan Daerah. Yogyakarta: UPP STIM YKPN.

Pedoman Umum EYD dan Pembentuk Istilah. (2010). Permendiknas No. 46 Tahun 2009. Yrama Widya: Bandung

P. Joko Subgyo, S.H. (2011). Metode Penelitian Dalam Teori dan Praktik. Jakarta: Rineka Cipta.

Riduwan, M.B.A. (2009). Pengantar Statistika Sosial. Bandung: penerbit alfabeta.

Sedarmayanti. (2009). Sumber Daya Manusia dan Produktivitas Kerja. Bandung: Penerbit CV. Mandar Maju

Singarimbun dan Effendi. (2011) .Metode Penelitian Survei. Jakarta : LP3ES.

Steers, Richard. (1980). Efektivitas organisasi. penerbit Erlangga, Jakarta

Sudana, I Made. (2011). Manajemen keuangan perusahaan. Jakarta: Erlangga.

Sugiyono. (2011). Metode Penelitian Administrasi. Alfabeta : Bandung.

Suparmoko. (2010) Keuangan Negara : Dalam teori dan praktik.Yogyakarta : BPFE.

Syamsuddin, Lukman. (2013). Manajemen Keuangan Perusahaan: Konsep aplikasi dalam perencanaan, pengawasan dan pengambilan keputusan. Jakarta: Rajawali Pers.

Thoha, Miftah. (2010). Ilmu administrasi publik kontemporer. Jakarta: Kencana.

Perundang-undangan :

Undang-Undang Nomor 5 Tahun 1962 tentang Perusahaan Daerah.

Undang-Undang Nomor 17 Tahun 2003 tentang Keuangan Negara.

Undang-Undang Nomor 32 Tahun 2004 tentang Pemerintahan Daerah.

Undang-Undang Nomor 33 Tahun 2004 tentang Perimbangan Keuangan Antara Pusat dan Daerah.

Peraturan Menteri Kesehatan Republik Indonesia Nomor 492 Tahun 2010 tentang Persyaratan Kualiatas Air Minum. 